Review

\title{
The Potential of Liposomes with Carbonic Anhydrase IX to Deliver Anticancer Ingredients to Cancer Cells in Vivo
}

\author{
Huei Leng Helena Ng ${ }^{1}$, Aiping Lu ${ }^{1,2, \dagger}$, Ge Lin ${ }^{3, \dagger}$, Ling Qin ${ }^{4, \dagger}$ and Zhijun Yang ${ }^{1,2, *}$
}

1 School of Chinese Medicine, Hong Kong Baptist University, 7 Baptist University Road, Kowloon Tong, Kowloon, Hong Kong 999077, China;

E-Mails: helena_ng@hkbu.edu.hk (H.L.H.N.); aipinglu@hkbu.edu.hk (A.L.)

2 Changshu Research Institute, Hong Kong Baptist University, Changshu Economic and Technological Development (CETD) Zone, Changshu 215500, China

3 School of Biomedical Sciences, Chinese University of Hong Kong, Area 39, CUHK, Shatin, NT, Hong Kong 999077, China; E-Mail: linge@cuhk.edu.hk

4 Musculoskeletal Research Laboratory, Department of Orthopaedics and Traumatology, The Chinese University of Hong Kong, Prince of Wales Hospital, Shatin, NT, Hong Kong 999077, China; E-Mail: qin@ort.cuhk.edu.hk

$\dagger$ These authors contributed equally to this work.

* Author to whom correspondence should be addressed; E-Mail: yzhijun@hkbu.edu.hk; Tel./Fax: +852-3411-2961.

Academic Editor: Bing Yan

Received: 4 November 2014 / Accepted: 16 December 2014 / Published: 24 December 2014

\begin{abstract}
Drug delivery nanocarriers, especially targeted drug delivery by liposomes are emerging as a class of therapeutics for cancer. Early research results suggest that liposomal therapeutics enhanced efficacy, while simultaneously reducing side effects, owing to properties such as more targeted localization in tumors and active cellular uptake. Here, we highlight the features of immunoliposomes that distinguish them from previous anticancer therapies, and describe how these features provide the potential for therapeutic effects that are not achievable with other modalities. While a large number of studies has been published, the emphasis here is placed on the carbonic anhydrase IX (CA-IX) and the conjugated liposomes that are likely to open a new chapter on drug delivery system by using immunoliposomes to deliver anticancer ingredients to cancer cells in vivo.
\end{abstract}


Keywords: immunoliposomes; anticancer ingredients; in vivo delivery; carbonic anhydronase IX (CA-IX); cancer cell penetrating peptides

\section{Introduction}

Cancers are among the leading causes of death worldwide, accountable for 82 million (14.8\%) of deaths in 2012 [1]. Despite extensive efforts made to improve the outcome of cancer therapy, cancer treatment is often limited by the therapeutic efficacy of anti-cancer agents. In many cases, anti-cancer agents are rapidly cleared from the circulation, or result in non-specific uptake by normal sensitive cells and tissues. One of the main focuses in current research is to develop targeted drug delivery systems that are able to enhance the treatment efficacy and reduce the side effects of anti-cancer agents in the clinical setting [2-5].

Nanocarriers created for therapeutics are comprised of therapeutic entities and components that assemble with therapeutic entities, such as lipids and polymers [6]. Lipidic drug carriers with water phase are generally called liposomes. While it may be argued that life forms may have never been developed without the protection of enclosing lipidic membranes, human cells are naturally and mainly comprised of lipid molecules. Hence the advancement in molecular lipid nanotechnology has permitted dramatic progress in human medical services.

Over the past 50 years, since the sealed phospholipids' lamellae of liposomes were observed to be able to differentially impede the diffusion of ions, the study of organized assemblies of phospholipids has taken place in diverse fields including pharmaceutical science, pharmacology, and cell biology. Since the early 1980s, liposomes have gained substantial interest commercially; however, neither strategy for the advancement of technology nor any general accepted area for its practical uses were exploited for many years [7]. From the end of 20th century, liposomal and lipid-complexed products became commercially available and recognized for their clinical applications. Liposomal science has established itself as a commercially important discipline, and it has been propelled forward by the understanding of how individual molecules including active ingredients and pharmaceutical excipients (effectively targeting molecules) assemble into lipidic nanocarriers [7].

Firstly, in this review, we briefly summarize the development of liposomal therapeutics. Next we discuss the key challenges of liposomes for in vivo delivery of anticancer ingredients. Finally, we discuss the role of CA-IX as a molecular target for liposomal-based cancer therapy. The utmost difficulty for liposomes is accurate in vivo delivery of the anticancer ingredients into cancer cells in the tissues of the body. Thus, our emphasis here is on the liposomes targeted delivery of anticancer ingredients into cancer cells in vivo. Although there are many experimental approaches utilizing liposomes that can be affected by external stimulation, we focus on systemic administration of anticancer ingredients to the cancer cells by liposomes in the tissues of the body.

\section{The Development of Liposomal Therapeutics}

Liposomes were first discovered by Alec D. Bangham and R. W. Horne [8,9] in the early 1960's. Liposomes are artificially self-assembled phospholipids mainly composed of a vesicle with a bilayer 
lamellar [10]. The integrity bilayer structure could release its contents after detergent treatment (structure-linked latency) [11]. Liposomes can be easily distinguished from micelles and hexagonal lipid phases by negative staining transmission electron microscopy [12]. In the presence of water, the phosphate heads of phospholipids are attracted to water, and line up to form a surface facing the water; the hydrocarbon tails of phospholipids are repelled by water, line up to form a surface facing the tails of another phospholipids; this combination forms a monolayer structure-micelle [13], or bilayer structures lamellar - liposomes [14]. Micelles and bilayers form in the polar medium by a process known as the hydrophobic effect [15]. One layer of hydrophilic heads faces outside of the liposomes, attracted to the water in the environment. Another layer of hydrophilic heads faces inside the liposomes, attracted by the water inside the liposomes [16]. Inside the hydrophobic membrane, liposomes encapsulate an aqueous phase of hydrophilic anticancer ingredients which cannot freely go through the lipids. On the other hand, hydrophobic chemicals can be inserted into the membrane. In this way, liposomes can carry both hydrophobic and hydrophilic molecules, and can be designed to deliver anticancer ingredients in vitro and in vivo. Intracellular delivery of anticancer ingredients encapsulated in the liposomes is mediated by endocytosis.

Research on liposomes has progressed from the first generation conventional vesicles to the second generation liposomes, in which long-circulating liposomes are obtained by modulating lipid composition, size, and charge of the vesicle. Liposomes may contain lower (or higher) pH aqueous anticancer ingredient solutions, and the anticancer ingredient will be neutralized to freely pass through the membrane. The $\mathrm{pH}$ changes can induce multilamellar vesicles to reassemble into unilamellar vesicles [17]. This process with electrostatic phenomenon was named as $\mathrm{pH}$-induced vesiculation. On the other hand, $\mathrm{pH}$ and/or ion changes can also form a $\mathrm{pH}$-gradient and or ion-gradient within the liposomes to increase the encapsulation of some electrolytic anticancer ingredients [18-20]. Generally, an acidic intra-liposomal aqueous environment was created using ammonium sulphate solution [21,22]. This approach allows protonation of the drug (e.g., gemcitabine) and prevents the back-diffusion of the drug from the liposome, resulting in an encapsulation efficiency of $\sim 90 \%$.

Additionally, polyethylene glycol (PEG) conjugated on the liposomal surface [23] allows liposomes to avoid detection by the reticuloendothelial system and other immune system, and show a longer blood-circulation time while reducing mononuclear phagocyte system (MPS) uptake. However, studies reported that PEG does not improve cellular uptake of liposome [24,25]. One hypothesis behind this was that the presence of PEG on the liposome surface not only prevents the MPS uptake, but also hinders the interaction of liposomes with cells and impedes the entry of the liposome into tumour cells [24]. In fact, how much PEG coating is required to increase systemic circulation without affecting the binding of liposome to tumor cell is not known. Interestingly, following the modification of the terminal PEG molecule, stealth liposomes can be linked with ligands that are expected to deliver pharmaceutical agents for cancer and other diseases. These ligands could be monoclonal antibodies [26-29], vitamins [30-32], or specific peptides $[33,34]$.

\section{Key Challenges of Liposomes for in Vivo Delivery of Anticancer Ingredients}

Over the years, liposome-based anticancer ingredient delivery system has been extensively researched to improve pharmacotherapy. The major challenge for liposome-based cancer therapy is to increase 
anticancer ingredient delivery to tumour tissues while minimizing anticancer ingredient toxicity in normal tissues. Liposomes are known for their biodegradability, biocompatibility, and flexibility in structure [35-37]. Several anticancer ingredients with liposomal formulation have been developed, including cisplatin [38], cytarabine [39], daunorobucin [40], doxorubicin [41], methotrexate [42], paclitaxel [43], gemcitabine [4,5,44,45], and vincristine [46]. The liposomal doxorubicin (Doxil ${ }^{\circledR}$, Janssen Biotech, Inc., Horsham, PA 19044, USA), is the first successful FDA (U.S. Food and Drug Administration)-approved liposomal therapy for cancer treatment [20,47-49], including ovarian/breast cancer, Kaposi's sarcoma, and multiple myeloma. As compared to the free anticancer ingredient, the liposomal-formulated doxorubicin exhibits enhanced tumour targeting and reduced systemic toxicity [20,50,51]. Recently, a meta-analysis [52] reported that liposomal-based therapy, in particular liposomal formulation of anthracyclines, had demonstrated lower toxicity incidence with better cardiac safety in randomised controlled trials as compared to the conventional anthracyclines treatment. Anthracyclines are cardio toxic drugs that in higher cumulative doses are associated with increased cardiotoxicity risk [53]. Using the liposomal formulation (including those with pegylated liposomes), the overall cardiac heart failure rate has been reduced [52]. Nonetheless, the natural properties of conventional liposomes have both pros and cons for anticancer drug delivery, and these are described in this section.

The first important property of liposomes is the anticancer ingredient release rates from liposomes. Anticancer ingredients encapsulated in liposomes are sometimes not bioavailable because they are not released from the liposomes with appropriate rates [54,55]. In contrast, liposome-based formulations for oral delivery can prolong the therapeutic effect of water soluble active pharmaceutical ingredients (API) by sustained release and controlled absorption [56].

The second key feature is the clearance of liposomes. Upon the administration of liposomes in vivo, liposomes interact with serum opsonins through opsonisation, resulting in the recognition and clearance of liposomes by the MPS in the liver and spleen [57,58]. Although the clearance of liposomes and the encapsulated anticancer ingredients from the circulation is via the cells of MPS, the interaction of liposomes with plasma proteins is determined mainly by physicochemical properties of the liposomes [59]. Several different strategies have been developed to increase the circulation time of liposomes by coating the surface of the liposomes with inert molecules, such as monosialoganglioside $[60,61]$ and PEG [62,63], to form a spatial barrier [48]. Monosialoganglioside or PEG occupies the space immediately adjacent to the liposomes surface, which tends to eliminate other macromolecules from this periliposomal space [49]. As a result, interaction of liposomes with serum opsonins is hindered, and thus interactions of MPS with such liposomes are impeded. Anticancer ingredients encapsulated in liposomes have substantial changes in the pharmacokinetics and biodistribution as they adopt the pharmacokinetics of the liposomes [64].

The third feature is the passive targeting of liposomes. In a healthy blood vessel, endothelial cells are bound together by tight junctions and form a monolayer of cells that lines the endothelium; this serves as a barrier to impede any large particles in the blood from leaking out of the vessel. In contrast, endothelium of tumour blood vessels is lined by defective endothelial cells. The tumour endothelial cells are not tightly bound together, resulting in large fenestration and loss of their normal barrier function [65]. Liposomes with sizes less than $400 \mathrm{~nm}$ can enter tumour tissues via the leaky tumour vasculature, but are kept within the bloodstream by the endothelial wall of healthy tissue vasculature [66]. This ability is named as the enhanced permeability and retention (EPR) effect. However, this passive 
targeting property of the current liposomal-based treatment has several limitations. Firstly, the permeability and porosity of tumour vessels varies with the type and stage of tumours [67]. Therefore, the effect of passive targeting may not be feasible in all tumours. Furthermore, homogenous targeting of tumour cells within a tumour is limited by the efficiency of anticancer ingredient diffusion [68]. Nonetheless, the current clinical use of liposomal-based therapies does not exhibit specific anticancer ingredient targeting at cellular level [51,68].

A fourth important feature of liposomes is the intracellular delivery of anticancer ingredients. While liposomes are large hydrophilic structures and not easy to fuse with cell membranes, anticancer ingredients are delivered into cells via endocytosis [69]. However, the endocytosed liposomes together with the encapsulated anticancer ingredients are often digested within endosomes by lysosomal enzymes before eliciting any biological effects [70]. Recently, ligands were conjugated to the liposomes surface to draw forth internalization of liposomes and their contents into cancer cells [71,72]. Many other strategies have also been proposed to enhance the endosomal escape of liposomes, such as cationic lipids [73] and $\mathrm{pH}$-sensitive peptides [74] that can enhance the delivery of liposomes. Furthermore, incorporation of fusogenic lipids or cell penetrating peptides (also named membrane active peptides) may increase cytoplasmic delivery [75].

Last but not least, a fifth significant consideration for liposomes is the diversity of cancer cells. To deliver anticancer ingredients to cancer cells, liposomes face the difficulty of cancer cell diversity. Cancer may occur by a single cell, which unchecked, reproduces aggressively and invades many other tissues, and chaotically destroys normal tissue cells. The wider the cancer spreads, the harder it becomes to eradicate.

With the recent advances in molecular technology, anticancer ingredient-loaded liposomes could be actively targeted at the cellular level by designing ligand-targeted immunoliposomes. This can be achieved by incorporating the targeting ligands, such as proteins, peptides, monoclonal antibodies, fragment antigen-binding ( $\mathrm{Fab})$, and single-chain variable fragment ( $\mathrm{scFv}$ ) [50,76], onto the surface of liposomes to specifically target tumour cells that overexpress a particular cell surface antigen or receptor. The use of antibodies conjugated to liposomes in order to confer target specificity was first introduced in the 1980s [77,78]. The molecular- or receptor-targeted immunoliposomes have since gained extensive attention as the new generation of targeted anticancer ingredient delivery system.

\section{The Rising of CA-IX as a Targeted Anticancer Drug Delivery System}

In the treatment of diverse cancers, anticancer ingredients such as Doxorubicin (Doxil), Camptothecin and Daunorubicin (Daunoxome) are marketed in liposome delivery drugs. Although the interesting property of liposomes is their natural ability to target some cancer related tissues, their in vivo targeting effectiveness is still perplexing. At this stage, the ideal liposomes are those that can distinguish between normal cells and cancer cells. Nevertheless, no such functional liposomes have been developed thus far. However, the CA-IX [23], carbonic anhydrase XII (CA-XII) [79] and cancer cell penetrating peptides [80] may help liposomes to overcome the diversity of cancer cells in order to deliver the anticancer ingredients to kill most of the cancer cells but not normal cells. In this review, the following discussion about CA-IX may provide some encouragement to pharmaceutical scientists to develop liposome-mediated targeted drug delivery therapeutics for cancer patients. 
Carbonic anhydrases (CAs) are a family of zinc metalloenzymes with 16 isoforms [81,82]. CAs are commonly known for their catalytic activity in the reversible hydration of cell-generated carbon dioxide into bicarbonate ions and protons $\left(\mathrm{CO}_{2}+\mathrm{H}_{2} \mathrm{O} \leftrightarrow \mathrm{HCO}_{3}{ }^{-}+\mathrm{H}^{+}\right)$. This catalytic reaction is an important event involved in many physiological and pathological processes, including respiration and transport of $\mathrm{CO}_{2}$ and $\mathrm{HCO}_{3}{ }^{-}$between metabolizing tissues and lungs, electrolyte secretion in various tissues, homeostasis of $\mathrm{pH}$ and $\mathrm{CO}_{2}$, several biosynthetic reactions (e.g., gluconeogenesis, lipogenesis and ureagenesis), bone resorption and calcification, and tumorigenicity [82-84].

Of all the CAs, CA-IX and CA-XII are overexpressed in many tumour types [82] and are associated with cancer progression, metastasis, and therapeutic response [81,85]. Both CA-IX and CA-XII are transmembrane proteins with an extracellular active site [86,87]. However, CA-IX has higher extracellular catalytic activity than CA-XII $[82,88]$. Several unique features of CA-IX has made it a suitable candidate for antigen-targeted drug delivery system in cancer therapy, including its structure, protein expression, and function in tumour cells.

\subsection{Biochemical Structure of CA-IX}

CA-IX protein consists of a long extracellular CA domain, a transmembrane region, and an intracellular $\mathrm{C}$ terminus (Figure 1) [89]. Besides that, the proteoglycan-like domain which lies in between the signal peptide and the CA domain has been suggested to play an important role in promoting efficient $\mathrm{CO}_{2}$ hydration at the acidic micro-environment of hypoxic tumours [90,91]. This proteoglycan-like domain is a unique feature of CA-IX which is absent from other $\alpha$-CAs. Localization of CA-IX on the tumour cell surface making it accessible to immunoliposomes, promotes its use as a candidate for targeted-drug delivery.

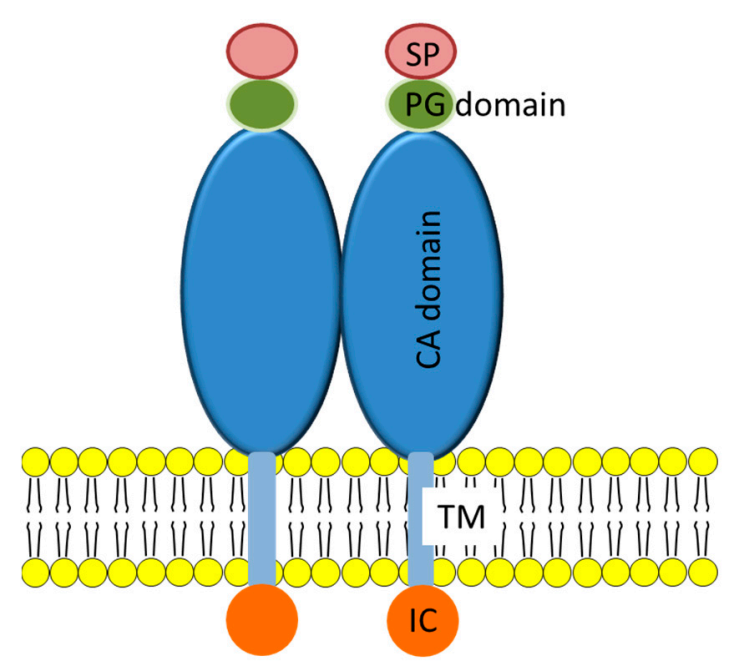

Figure 1. Dimeric structure of CA-IX. SP, signal peptide; PG, proteoglycan-like segment; CA, carbonic anhydrase domain; TM, transmembrane anchor; IC, intracytoplasmic tail [92].

\subsection{Functions of CA-IX in Tumour Tissue}

Hypoxia is the key driver of CA-IX expression in tumour cells, and is induced by an HIF-1 $\alpha$-mediated signalling cascade $[82,85]$. Activation of HIF-1 $\alpha$ (Hypoxia-inducible factor 1- $\alpha$ ) leads to a glycolytic switch in the tumour cell metabolism pathway, resulting in increased production and export of lactic 
and carbonic acids to the extracellular space, and leads to a decline in extracellular $\mathrm{pH}(\mathrm{pHe})$. This acidified extracellular space can disrupt the intracellular $\mathrm{pH}(\mathrm{pHi})$, which will in turn affect basic cell function [81]. However, CA-IX is the key defensive player of the pHi. The overexpression of CA-IX during hypoxia catalyzes the hydrolysis of $\mathrm{CO}_{2}$ to $\mathrm{HCO}_{3}{ }^{-}$and $\mathrm{H}^{+}$in the extracellular microenvironment $[81,93,94] . \mathrm{HCO}_{3}{ }^{-}$is actively transported via the sodium bicarbonate co-transporter into the cancer cell, thereby buffering pHi and maintaining cell survival $[81,93,94]$. On the other hand, the $\mathrm{H}^{+}$remains extracellularly, generating an increasingly acidic microenvironment that promotes tumour cell invasiveness $[81,93,94]$. Importantly, CA-IX has a maximal catalytic activity at pH values of 6.49, typical of the acidic microenvironment of the hypoxic solid tumours in which CA-IX is overexpressed [91].

In addition to the regulation of intratumoral $\mathrm{pH}$ and tumour cell survival, studies [84,95-97] suggest that CA-IX regulates cell adhesion, migration and proliferation, indicating that CA-IX might enhance the metastatic potential of tumour cells. E-cadherin is a key regulator of cell-cell adhesion in epithelial tissues, in which the loss or destabilization of its function is linked to tumour invasion. Švastová et al. [97] showed that CA-IX competed with E-cadherin to modulate E-cadherin-mediated cell adhesion via interaction with $\beta$-catenin. CA-IX-expressing Madin-Darby canine kidney (MDCK) cells displayed a higher degree of cell dissociation as compared to normal MDCK cells, and the co-precipitation of CA-IX with $\beta$-catenin was indicated to be responsible for the lower cell adhesion capacity [97]. CA-IX-transfected C33A cell line (a human cervical carcinoma cell line) exhibited reduced cell-cell adhesion and increased cell motility via Rho-GTPase-mediated epithelial-mesenchymal transition [84]. Furthermore, CA-IX has also been reported to promote cell proliferation in renal cell carcinoma [98], cervical cancer cell [98], colorectal tumours [95], and gastric adenocarcinoma (AGS (the human gastric epithelial) cell line) [99].

\subsection{Protein Expression of $C A-I X$}

CA-IX is overexpressed in many solid tumours but not in their corresponding normal tissues [100]. Previous studies reported that CA-IX expression was up-regulated and associated with poor prognosis in cancers of the lung [101-103], breast [104-106], liver [107,108], cervix [109-112], colon [95,113], ovaries [114], bladder [115], head and neck [116-118], brain [119,120], and oral cavity [121,122]. Importantly, CA-IX expression in normal tissue is limited to the basolateral surface of gastric, intestinal (proliferating crypt enterocytes of the duodenum, jejunum and ileal mucosa), and gallbladder epithelia in human [96,123].

A study by Gut et al. [124] showed that mice with global knockout (KO) of CA-IX developed gastric hyperplasia of the glandular epithelium with numerous cysts. Nonetheless, the CA-IX KO mice developed normally and showed normal levels of gastric $\mathrm{pH}$, acid secretion and serum gastrin [124]. Given that there are 16 isoforms of CAs, there could be a functional redundancy amongst the CA isoforms. It is also important to note that CA-IX deficiency in mice did not promote tumorigenecity [125].

Differential expression of CA-IX in normal vs. tumour cells can be explained by the mechanism of transcription for CA-IX. In the promoter region of the CA-IX gene, a hypoxia responsive element is located adjacent to its transcriptional start site [126]. The hypoxia responsive element in the CA-IX gene promoter binds to hypoxia-inducible factor $1 \alpha$ (HIF-1 $\alpha$ ), and this is expressed in many tumour types, overlapping with vascular endothelial growth factor (VEGF) mRNA and the hypoxia marker 
pimonidazole [126]. Interestingly, the promoter region of CA-IX gene has neither a TATA box nor a consensus initiator motif [89], suggesting that CA-IX is tightly regulated by hypoxia, and that HIF-1 $\alpha$ may interact directly with the basal transcriptional machinery operating on this gene [126].

Hypoxia is a salient feature of rapidly growing malignant tumours and their metastases. During the early stage of tumour development, tissue hypoxia occurs due to insufficient blood supply [127]. However, angiogenesis and neovascularization during tumour growth do not improve the tissue hypoxia status as these fail to provide adequate oxygen supply to the tumour [127]. Reduced oxygen availability in tumour tissue leads to the activation of a core cellular response to hypoxia, the transcription factors HIF-1 $\alpha$ [128]. Conversely, in normoxia tissues, HIF-1 $\alpha$ is modified by oxygen-sensitive prolyl hydroxylases and asparaginyl hydroxylase, making it recognisable by the tumour suppressor von Hippel Lindau protein, resulting in the suppression of CA-IX expression [88].

It is well-accepted that one-size-fits-all approach is not applicable for cancer treatment. For example, triple-negative breast cancer, which accounts for about $23 \%$ of all breast cancer cases [129], is defined as lacking expression of oestrogen receptor, progesterone receptor, and HER2. Thus, HER2-targeted treatment is not suitable for triple-negative breast cancer cases. Importantly, about $43 \%$ of HER-2 negative breast cancer type expressed CA-IX [130], and CA-IX expression is associated with shorter relapse-free survival and worse survival [131]. Table 1 lists some examples of the differential tissue expression of HER2 and CA-IX in various tumour tissues from patients. This table indicates that, in some cancer types, HER2 might be a better molecular target than CA-IX for anticancer drug delivery, while in other cancers, CA-IX may be a better molecular target. Therefore, the most studied HER2-targeted treatment might only be beneficial for a small population of cancer patients.

Table 1. Examples of tissue expression of HER2 and CA-IX in various carcinomas.

\begin{tabular}{|c|c|c|}
\hline Carcinoma & HER2 Expression & CA-IX Expression \\
\hline \multicolumn{3}{|l|}{ Bladder } \\
\hline micropapillary carcinomas & $15 \%$ of $61[132]$ & N.D. \\
\hline typical urothelial carcinoma & $9 \%$ of $100[132]$ & $71 \%$ of 340 cases [133] \\
\hline Brain & N.D. & $97 \%$ of 112 cases [ 120$]$ \\
\hline Breast & $18 \%$ of 1134 cases [129] & $30 \%$ of 740 cases [130] \\
\hline Cervix & $14 \%$ of 50 cases $[134]$ & $82 \%$ of 221 cases [112] \\
\hline Colorectal & $4 \%$ of 51 cases $[135]$ & $49 \%$ of 80 cases $[113]$ \\
\hline Endometrial & $12 \%$ of 286 cases $[136]$ & $89 \%$ of 92 cases [137] \\
\hline Gastric & $12 \%$ of 131 cases [138] & $48 \%$ of 42 cases [139] \\
\hline Gastroesophageal & $24 \%$ of 100 cases $[138]$ & $49 \%$ of 39 cases [139] \\
\hline Head and neck & $7 \%$ f 57 cases $[140]$ & $26 \%$ of 72 cases $[141]$ \\
\hline Kidney & Detected in normal tissue & \\
\hline clear cell renal cell carcinoma & Rare [142] & $99 \%$ of 186 cases [ 143$]$ \\
\hline Liver & N.D. & $30 \%$ of 69 cases $[108]$ \\
\hline Lung & $13 \%$ of 563 cases $[144]$ & $82 \%$ of 175 cases [ 103$]$ \\
\hline Oral cavity & $1 \%$ of 196 cases $[145]$ & $43 \%$ of 80 cases $[122]$ \\
\hline Ovarian & $29 \%$ of 50 cases $[146]$ & $18 \%$ of 205 cases $[114]$ \\
\hline Prostate & $14 \%$ of 216 cases [ 147$]$ & $0 \%$ of 59 cases $[148]$ \\
\hline
\end{tabular}

Expressions were detected with immunohistochemistry, enzyme-linked immunosorbent assay, Western blot, or fluorescence in situ hybridization assays. N.D., not determined. 


\subsection{CA-IX-Targeted Therapeutic Approaches}

Binding of antibodies to cell surface antigens is able to lyse cells by complement activation or by antibody-mediated cell cytotoxicity (ADCC). Direct binding of the monoclonal antibody (mAb) to CA-IX can elicit an anti-tumour response due to ADCC. G250 is an IgG mAb that was first discovered in the 1980s, it was originally isolated from a hybridoma produced from splenocytes of mice following immunization with human renal-cell carcinoma cells [149]. G250 mAb has since been shown to recognize a conformational determinant of CA-IX [150,151]. However, G250 is not capable of inducing ADCC in renal-cell carcinoma cells. Instead, a human/mouse chimeric version of G250, cG250 (mouse variable fragment (Fv) and human IgG1 fragment crystallizable $(\mathrm{Fc}))$, has been developed [152]. Studies [152,153] showed that cG250 could initiate cell lysis through ADCC in CA-IX-positive cells and that cG250-induced ADCC was significantly enhanced by co-treatment with interleukin 2 (IL-2). cG250 (Girentuximab) is currently marketed by WILEX AG (Munich, Germany) under the trade name RENCAREX $^{\circledR}$. Phase I, II and III clinical trials demonstrated that Girentuximab was safe, well tolerated, and demonstrated clinical benefit and disease stabilization alone [154-156] and together with IL-2 [157,158] or interferon (IFN)- $\alpha$ [159] treatment. Reports showed that most, if not all, adverse effects developed during the treatment period were attributable to the administration of IL-2 and IFN- $\alpha[158,159]$. However, phase III clinical trial of Girentuximab in the treatment of clear cell renal cell carcinoma showed no improvement disease free survival rate [154].

Zat'ovičova et al. [160] recently characterised a new CA-IX-specific mouse mAb VII/20. VII/20 mAb was directed to the catalytic domain of CA-IX, in which the receptor-mediated internalization was induced upon the binding of VII/20 mAb to CA-IX. Although in vivo study showed that VII/20 limited tumour growth in HT-29 colorectal xenografts, the effect was modest when tumours were established prior to treatment [160]. However, incorporation of VII/20 mAb onto liposomes might facilitate drug delivery to CA-IX-positive tumour cells and thereby enhance therapeutic output. On the other hand, Bayer HealthCare AG, Berlin, Germany [161] identified a 3ee9 mAb that selectively co-immunoprecipitated with and internalized by CA-IX-positive cells. The therapeutic application of this antibody has thus far been tested with monomethyl auristatin E as an antibody-drug conjugate (BAY79-4620) in several preclinical human xenograft tumour models [161]. Nonetheless, the development and characterization of new CA-IX-specific antibodies is still ongoing.

\subsection{Optimization of Antibody-Targeted Immunoliposomes}

PEG has been widely used as polymeric steric stabilizer. It is particularly useful because of its ease of preparation, relatively low cost, its molecular weight and structure can be modulated, and it serves as a linker to lipids or protein $[48,162]$. The most commonly used method to incorporate PEG in the liposomal membrane is via a cross-linked lipid (i.e., distearoylphosphatidylethanolamine (DSPE)-PEG. DSPE-PEG containing a sulfhydryl-reactive group, such as maleimide, readily reacts with the thiol group of cysteine or the reduced thiol group of Fab or scFv fragments.

Using G250 as an example, G250 can be modified for the conjugation onto the liposomes. G250 is an IgG molecule which is composed of two light and two heavy chains, held together by non-covalent bonding as well as a number of disulfide bonds. The hypervariable sequence in the $N$-terminal of the heavy-light chain proximity on each of the basic IgG-type monomeric structures are antigen binding 
sites (Figure 2) [162,163]. One of the methods to modify G250 mAb is enzyme digestion, as illustrated in Figure 2. Enzymatic digestion with papain produces two Fab fragments of the IgG molecule, each containing an antigen binding site, and one larger Fc (fragment crystallizable) fragment containing only the lower portions of the two heavy chains [164]. Otherwise, pepsin cleavage produces one large $F(a b)_{2}$ fragment containing two antigen binding sites and many smaller peptide fragments from extensive degradation of the Fc region [164]. Specific reduction of the disulphide bonds which hold the $F(a b)_{2}$ fragment together using 2-mercaptoethylamine- $\mathrm{HCl}(\mathrm{MEA}-\mathrm{HCl})$ produces two Fab fragments, each of which has one antigen binding site. The advantage of using a Fab fragment instead of whole body antibody is the removal of the Fc region during enzymatic digestion, in which the immunogenic effect of the Fc portion increased reticuloendothelial system clearance through specific recognition by phagocytic cells carrying Fc receptor [162]. Additionally, the thiol group of the Fab fragment is readily bound with the maleimide of the DSPE-PEG to form an immunoliposomes.

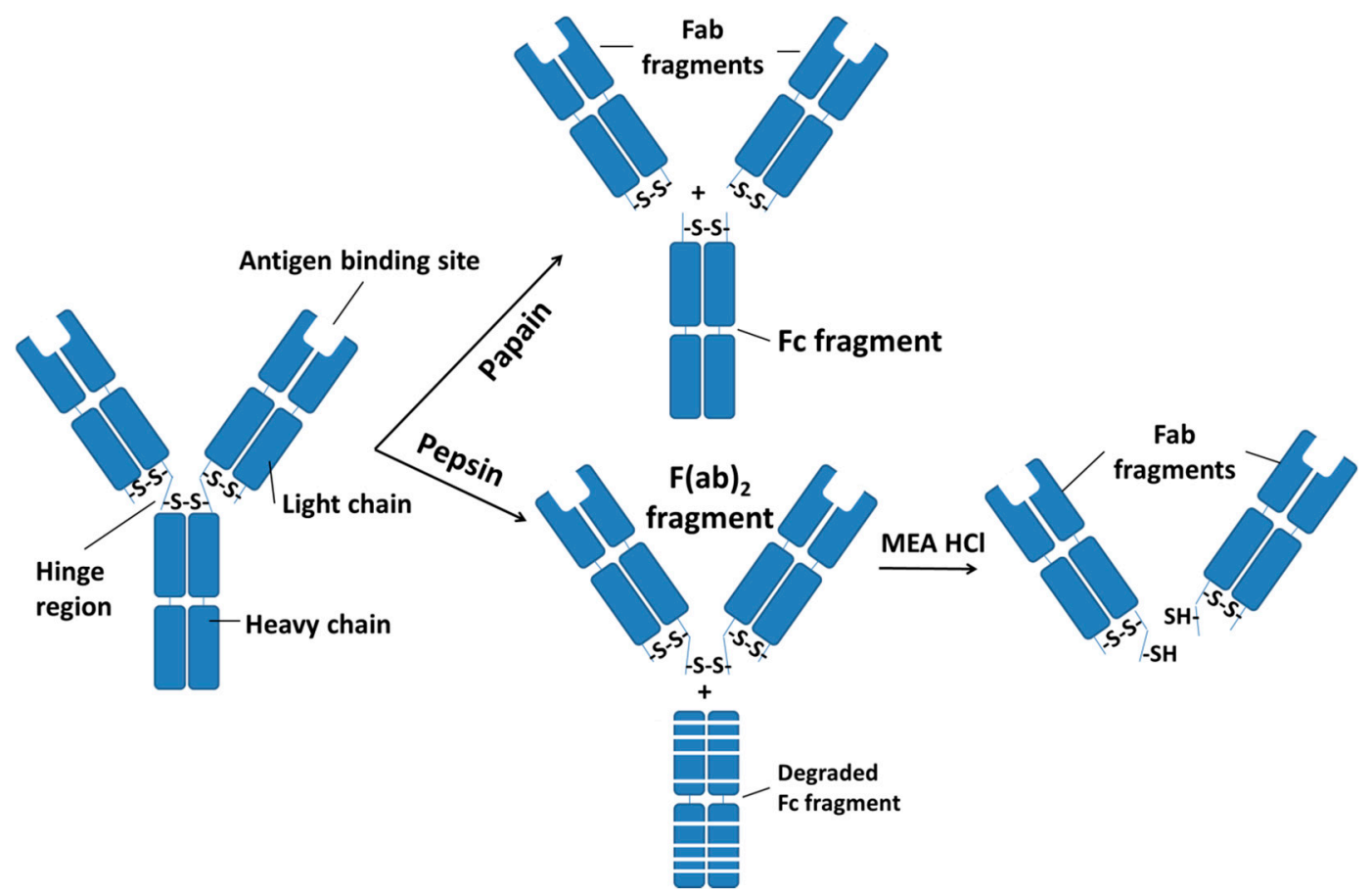

Figure 2. Introduction of sulfhydryl group in $\mathrm{IgG}$ antibodies (such as $\mathrm{G} 250 \mathrm{mAb}$ ) via enzymatic digestion. Enzyme digestion of $\mathrm{IgG}$ antibodies with papain results in cleavage of the hinge region above the interchain disulfides. This produces two identical Fab fragments (heavy-light chain pairs), each containing one antigen binding site and one Fc region. Pepsin digestion of $\operatorname{IgG}$ antibodies cleaves below the disulphides in the hinge region, resulted in the formation of a bivalent fragment $F(a b)_{2}$. The remaining Fc region is extensively degraded into smaller peptide fragments. $\mathrm{F}(\mathrm{ab})_{2}$ fragments are subsequently reduced with $\mathrm{MEA}-\mathrm{HCl}$ and produced two $\mathrm{Fab}$ fragments.

\section{Immunoliposome}

One of the most studied ligand-targeted immunoliposomes was the human epidermal growth factor receptor 2 (HER2)-targeted immunoliposomes. HER2 is overexpressed in SKBR-3 or BT-474 breast cancer cells in vitro [27], and it is overexpressed at 1000-fold higher than normal in $\sim 25 \%$ of breast 
cancer cases [165,166]. Most [27,28,167,168], but not all [169] studies reported significant enhanced anti-tumour efficacy with the HER2-targeted immunoliposomes. Park et al. [28] showed that HER2-targeted doxorubicin liposomes with internalizing ligand exhibited a significant increase in anti-tumour efficacy and reduced systemic toxicity compared with the non-targeted doxorubicin liposomes. However, the therapeutic efficacy of the non-targeted doxorubicin liposomes was not different from that of the HER2-targeted doxorubicin liposomes without the internalizing ligand [169]. This highlights the importance of the target antigen selection, as well as the importance of liposome internalization during the design of the immunoliposomes. Other antibodies used to target liposomes include: anti-CD22 antibody targeting Non-Hodgkin's Lymphoma [170]; anti-CD19 antibody targeting malignant B cells [171]; anti-CD44 antibody targeting cancer stem cells [45,172]; and anti-MT1-MMP (membrane type 1 matrix metalloproteinase) targeting tumour and neovascularity [173].

Recently, a doxorubicin-loaded anti-EGFR (epidermal growth factor receptor) immunoliposome (anti-EGFR ILs-dox) phase I clinical trial for patients with EGFR-overexpressing advanced solid tumours was completed [174]. In this phase I clinical trial, Fab fragment of cetuximab, an EGFR mAb, was conjugated onto PEGylated liposomes containing doxorubicin. The primary end point of this study was the maximum tolerated dose of anti-EGFR ILs-dox, and it was reported that anti-EGFR ILs-dox was well tolerated up to $50 \mathrm{mg}$ doxorubicin per $\mathrm{m}^{2}$. The best response to the six-month treatment included one complete response, one partial response, and ten stable disease lasting 2-12 months (median 5.75 months). A phase I clinical trial for MCC-465, a GAH-targeted doxorubicin-loaded immunoliposome, has also been completed [175]. In this study, patients with metastatic or recurrent stomach cancer were recruited. Maximum tolerated dose was $32.5 \mathrm{mg}$ doxorubicin per $\mathrm{m}^{2}$ for a 3-week schedule. Although no antitumor response was observed, stable disease was observed in 10 out of 18 patients. Interestingly, no palmar-plantar erythrodysaesthesia, cardiotoxicity, or cumulative toxicity was observed in the patients in these studies, indicating immunoliposome had reduced systemic toxic side effects.

The development of ligand-targeted immunoliposomes is still at its preliminary stage, and these newly emerging drug delivery systems lack long-term results. With the extensive research in this area in the past, ligand-targeted immunoliposomes have shown convincing pre-clinical results with enhanced therapeutic efficacy over the passively-targeted liposomes $[76,176]$. Nonetheless, new challenges have arisen from these past ligand-targeted immunoliposomes design, such as internalization into the tumour cells, immune recognition, restricted diffusion and penetration through the tumour tissue, non-specific binding by serum proteins, toxic side effects of liposomal lipid composition, and translation from pre-clinical animal models to clinical studies [76,177]. In recent years, carbonic anhydrase IX (CA-IX) has drawn a lot of attention from researchers as a potential candidate for antigen-targeted anticancer ingredient delivery.

\subsection{CA-IX-Targeted Immunoliposomes}

The first CA-IX-targeted immunoliposomes was developed by Shinkai and colleagues [178] in 2001, In this study [178], magnetoliposomes (MLs) were conjugated with the Fab fragment of the G250 antibody to induce hyperthermia in cancer cells. MLs consist of magnetisable iron oxide cores (magnetite, $\mathrm{Fe}_{3} \mathrm{O}_{4}$ ) which can mediate a magnetic field-induced hyperthermia therapy. In vitro uptake of G250 MLs 
was five times higher in the CA-IX-expressed mouse renal-cell carcinoma cells, and was 1.5 times higher than the non-targeted MLs [178]. Furthermore, 50\% of the injected G250 MLs accumulated in the tumour tissues; this was approximately 27 times higher than that of the non-targeted MLs [178]. Non-specific uptake of G250 MLs was mainly discovered in the blood and the liver, and this could be due to the uptake by macrophages and Kupffer cells [178]. However, the non-specific uptake of G250 MLs was lower than that of the non-targeted MLs, and accumulation of G250 MLs in the liver did not induce tissue necrosis. Treatment of G250 MLs in mice has significantly reduced the tumour tissue weight and increased the survival time of mice. This study presented a novel approach using CA-IX as the antigen targeted for liposome delivery and showed that CA-IX is a promising target for cancer therapy.

Recently, we developed a CA-IX-targeted immunoliposome delivery system for human lung cancer in vitro [26]. In this study, docetaxel was encapsulated in the CA-IX targeted immunoliposome and was delivered to human lung cancer cells in vitro. As compared to the non-targeted immunoliposome, CA-IX-targeted immunoliposome exhibited a 1.65-fold increase in binding affinity to CA-IX-positive human lung cancer cells. Docetaxel delivered via CA-IX-targeted immunoliposome induced a strong cytotoxicity effect in CA-IX-positive human lung cancer cells [26]. However, the effect of anti-cancer agents delivered via CA-IX-targeted immunoliposome has yet to be examined in vivo.

\subsection{Limitations of CA-IX-Targeted Immunoliposomes}

As mentioned above, the ideal liposomes are those that have target specificity for tumour cells but not to normal cells. However, such liposomes have not yet been developed. To date, the identified ligands for anticancer treatment do not embrace all cancer types. Moreover, ligands that have high ratio of tumour-to-normal tissue levels are essential to reduce side effects of cytotoxic drugs. CA-IX is expressed in many tumour types, thus it might serve as an additional cancer-specific ligand-targeted anticancer treatment. While CA-IX might not be the magic bullet for anticancer treatment of all cancer types, research on CA-IX targeted drug delivery system is warranted for a more comprehensive anticancer drug delivery system that could be beneficial for larger populations of cancer patients. Current research on CA-IX-targeted liposomal drug delivery system is however, very limited. CA-IX-targeted immunoliposome, theoretically, would be an ideal liposomal-based therapy for various types of cancer. However, more studies, including both in vitro and in vivo, are essential to prove the concept before moving on to clinical trials, Furthermore, CA-IX is expressed in the basolateral surface of gastrointestinal tissue, and gallbladder epithelia in human $[96,123]$. Therefore, it is crucial to determine the maximum tolerated dose of anticancer ingredients in cancer patients with minimum side effects.

Furthermore, Askoxylakis et al. [179] suggested that expression of the CA-IX protein is unstable, and microenvironment-dependent. The scientific literature lacks information about the onset of CA-IX expression in the course of carcinogenesis, the percentage of CA-IX-positive cells, and the amount of protein expressed in tumour tissues at different disease stages. Thus, more research is needed in order to design a proper treatment regime for patients. The first identified peptide ligand for the CA-IX receptor through phage display technology is CaIX-P1 $[179,180]$. However, to the best of our knowledge, the endogenous ligand of the CA-IX receptor is unknown. Whether there will be an endogenous ligand present to compete with the CA-IX targeted immunoliposome for the CA-IX receptor, and thus limit the therapeutic outcome of CA-IX targeted immunoliposome, is currently unknown. 


\section{Conclusions}

This review has focused on targeted liposomal technology and summarized CA-IX in relation to the principal liposomes formulations. CA-IX is a tumour-specific antigen for many tumour tissues, but not for their corresponding normal tissues. While current research on the CA-IX-targeted therapeutic approach has been mainly focused on human renal-cell carcinoma cells, this can certainly be expanded into other tumour types. To date, the therapeutic effect of CA-IX-targeted drug delivery to other tumour types has not been documented. Furthermore, research on CA-IX-targeted liposomal drug delivery system is very limited. Preclinical and clinical studies have demonstrated clear evidence that immunoliposomes exhibit specificity in the immune system with more powerful cytotoxics to enhance anticancer therapeutic efficacy and reduce side effects by targeted delivery, and thus warrant further research for clinical applications.

\section{Acknowledgments}

We would like to thank the Hong Kong Baptist University for the Faculty Research Grant support and the University Grants Committee of Hong Kong for the General Research Fund (GRF) support.

\section{Author Contributions}

Huei Leng Helena Ng has reviewed most of the carbonic anhydrases IX and XII under Zhijun Yang's instruction. Aiping Lu, Ge Lin, and Lin Qin have given guidance and checked the review. Zhijun Yang has reviewed the liposomes for the drug delivery and organized the whole review.

\section{Conflicts of Interest}

The authors declare no conflict of interest.

\section{References}

1. GLOBOCAN 2012: Estimated cancer incidence, mortality and prevalence worldwide in 2012. Available online: http://globocan.iarc.fr/Default.aspx (accessed on 18 December 2014).

2. Celia, C.; Trapasso, E.; Locatelli, M.; Navarra, M.; Ventura, C.A.; Wolfram, J.; Carafa, M.; Morittu, V.M.; Britti, D. Anticancer activity of liposomal bergamot essential oil (BEO) on human neuroblastoma cells. Colloids Surf. B Biointerfaces 2013, 112, 548-553.

3. Wolfram, J.; Suri, K.; Huang, Y.; Molinaro, R.; Borsoi, C.; Scott, B.; Boom, K.; Paolino, P.; Fresta, M.; Wan, J.; et al. Evaluation of anticancer activity of celastrol liposomes in prostate cancer cells. J. Microencapsul. 2014, 31, 501-507.

4. Cosco, D.; Bulotta, A.; Ventura, M.; Celia, C.; Calimeri, T.; Perri, G.; Paolino, D.; Costa, N.; Neri, P.; Tagliaferri, P.; et al. In vivo activity of gemcitabine-loaded PEGylated small unilamellar liposomes against pancreatic cancer. Cancer Chemother. Pharmacol. 2009, 64, 1009-1020.

5. Paolino, D.; Cosco, D.; Celano, M.; Moretti, S.; Puxeddu, E.; Russo, D.; Fresta, M. Gemcitabine-loaded biocompatible nanocapsules for the effective treatment of human cancer. Nanomedicine (Lond.) 2013, 8, 193-201. 
6. Davis, M.E.; Chen Z.G.; Shin, D.M. Nanoparticle therapeutics: an emerging treatment modality for cancer. Nat. Rev. Drug Discov. 2008, 7, 771-782.

7. Janoff, A.S. Liposomes: Rational Design; Marcel Dekker, Inc.: New York, NY, USA, 1999.

8. Bangham, A.D.; Horne, R.W.; Glauert, A.M.; Dingle, J.T.; Lucy, J.A. Action of saponin on biological cell membranes. Nature 1962, 196, 952-955.

9. Horne, R.W.; Bangham, A.D.; Whittaker, V.P. Negatively stained lipoprotein membranes. Nature 1963, 200, 1340, doi:10.1038/2001340a0.

10. Bangham, A.D.; Horne, R.W. Negative staining of phospholipids and their structural modification by surface-active agents as observed in the electron microscope. J. Mol. Biol. 1964, 8, 660-668.

11. Bangham, A.D.; Standish, M.M.; Weissmann, G. The action of steroids and streptolysin S on the permeability of phospholipid structures to cations. J. Mol. Biol. 1965, 13, 253-259.

12. Yashroy, R.C. Lamellar dispersion and phase separation of chloroplast membrane lipids by negative staining electron microscopy. J. Biosci. 1990, 15, 93-98.

13. MacNaught, A.D.; Wilkinson A.R. Compendium of Chemical Terminology: IUPAC Recommendations, 2nd ed.; Blackwell Science: Oxford, UK, 1997.

14. Feigenson, G. Phase behavior of lipid mixtures. Nat. Chem. Biol. 2006, 2, 560-563.

15. Wiggins, P. Role of water in some biological processes. Microbiol. Rev. 1990, 54, 432-449.

16. Van Meer, G.; Voelker, D.R.; Feigenson, G.W. Membrane lipids: Where they are and how they behave. Nat. Rev. Mol. Cell Biol. 2008, 9, 112-124.

17. Hauser, H.; Gains, N. Spontaneous vesiculation of phospholipids: A simple and quick method of forming unilamellar vesicles. Proc. Natl. Acad. Sci. USA 1982, 79, 1683-1687.

18. Cullis, P.R. Liposomes by accident: Commentary. J. Liposome Res. 2000, 10, ix-xxiv.

19. Mayer, L.D.; Bally, M.B.; Cullis, P.R. Uptake of adriamycin into large unilamellar vesicles in response to a pH gradient. Biochim. Biophys. Acta Biomembr. 1986, 857, 123-126.

20. Barenholz, Y. Doxil ${ }^{\circledR}$-The first FDA-approved nano-drug: Lessons learned. J. Control. Release 2012, 160, 117-134.

21. Celano, M.; Calvagno, M.G.; Bulotta, S.; Paolino, D.; Arturi, F.; Rotiroti, D.; Filetti, S.; Fresta, M.; Russo, D. Cytotoxic effects of Gemcitabine-loaded liposomes in human anaplastic thyroid carcinoma cells. BMC Cancer 2004, 4, doi:10.1186/1471-2407-4-63.

22. Calvagno, M.G.; Celia, C.; Paolino, D.; Cosco, D.; Iannone, M.; Castelli, F.; Filetti, S.; Fresta, M.; Russo, D. Effects of lipid composition and preparation conditions on physical-chemical properties, technological parameters and in vitro biological activity of gemcitabine-loaded liposomes. Curr. Drug Deliv. 2007, 4, 89-101.

23. Lasic, D.; Martin, F. Stealth Liposomes; CRC Press: Boca Raton, FL, USA, 1995.

24. Parr, M.J.; Masin, D.; Cullis, P.R.; Bally, M.B. Accumulation of liposomal lipid and encapsulated doxorubicin in murine Lewis lung carcinoma: the lack of beneficial effects by coating liposomes with poly(ethylene glycol). J. Pharmacol. Exp. Ther. 1997, 280, 1319-1327.

25. Nag, O.K.; Awasthi, V. Surface engineering of liposomes for stealth behavior. Pharmaceutics 2013, 5, 542-569.

26. Wong, B.C.; Zhang, H.; Qin, L.; Chen, H.; Fang, C.; Lu, A.; Yang, Z. Carbonic anhydrase IX-directed immunoliposomes for targeted drug delivery to human lung cancer cells in vitro. Drug Des. Dev. Ther. 2014, 8, 993-1001. 
27. Kirpotin, D.; Park, J.W.; Hong, K.; Zalipsky, S.; Li, W.L.; Carter, P.; Benz, C.C.; Papahadjopoulos, D. Sterically stabilized Anti-HER2 immunoliposomes: Design and targeting to human breast cancer cells in vitro. Biochemistry 1997, 36, 66-75.

28. Park, J.W.; Hong, K.L.; Kirpotin, D.B.; Colbern, G.; Shalaby, R.; Baselga, J.; Shao, Y.; Nielsen, U.B.; Marks, J.D.; Moore, D.; et al. Anti-HER2 immunoliposomes: Enhanced efficacy attributable to targeted delivery. Clin. Cancer Res. 2002, 8, 1172-1181.

29. Brown, B.S.; Patanam, T.; Mobli, K.; Celia, C.; Zage, P.E.; Bean, A.J.; Tasciotti, E. Etoposide-loaded immunoliposomes as active targeting agents for GD2-positive malignancies. Cancer Biol. Ther. 2014, 15, 851-861.

30. Raju, A.; Muthu, M.S.; Feng, S.S. Trastuzumab-conjugated vitamin E TPGS liposomes for sustained and targeted delivery of docetaxel. Expert Opin. Drug Deliv. 2013, 10, 747-760.

31. Turk, M.J.; Waters, D.J.; Low, P.S. Folate-conjugated liposomes preferentially target macrophages associated with ovarian carcinoma. Cancer Lett. 2004, 213, 165-172.

32. Paolino, D.; Licciardi, M.; Celia, C.; Giammona, G.; Fresta, M.; Cavallaro, G. Folate-targeted supramolecular vesicular aggregates as a new frontier for effective anticancer treatment in in vivo model. Eur. J. Pharm. Biopharm. 2012, 82, 94-102.

33. Chen, C.W.; Lu, D.W.; Yeh, M.K.; Shiau, C.Y.; Chiang, C.H. Novel RGD-lipid conjugate-modified liposomes for enhancing siRNA delivery in human retinal pigment epithelial cells. Int. J. Nanomed. 2011, 6, 2567-2580.

34. Li, W.; Su, B.; Meng, S.Y.; Ju, L.X.; Yan, L.H.; Ding, Y.M.; Song, Y.; Zhou, W.; Li, H.Y.; Tang, L.; et al., RGD-targeted paramagnetic liposomes for early detection of tumor: In vitro and in vivo studies. Eur. J. Radiol. 2011, 80, 598-606.

35. Arias, J.L. Liposomes in drug delivery: A patent review (2007-present). Expert Opin. Ther. Pat. 2013, 23, 1399-1414.

36. Kim, C.K.; Lim, S.J. Recent progress in drug delivery systems for anticancer agents. Arch. Pharm. Res. 2002, 25, 229-239.

37. Zou, Y.Y.; Ling, Y.H.; Reddy, S.; Priebe, W.; Perezsoler, R. Effect of vesicle size and lipid composition on the in vivo tumor selectivity and toxicity of the non-cross-resistant anthracycline annamycin incorporated in liposomes. Int. J. Cancer 1995, 61, 666-671.

38. Harrington, K.J.; Rowlinson-Busza, G.; Uster, P.S.; Stewart, J.S. Pegylated liposome-encapsulated doxorubicin and cisplatin in the treatment of head and neck xenograft tumours. Cancer Chemother. Pharm. 2000, 46, 10-18.

39. Koller-Lucae, S.K.M.; Schott, H.; Schwendener, R.A. Low density lipoprotein and liposome mediated uptake and cytotoxic effect of N-4-octadecyl-1- $\beta$-D-arabinofuranosylcytosine in Daudi lymphoma cells. Br. J. Cancer 1999, 80, 1542-1549.

40. Forssen, E.A. The design and development of DaunoXome(R) for solid tumor targeting in vivo. Adv. Drug Deliv. Rev. 1997, 24, 133-150.

41. Hong, R.L.; Tseng, Y.L. Phase I and pharmacokinetic study of a stable, polyethylene-glycolated liposomal doxorubicin in patients with solid tumors-The relation between pharmacokinetic property and toxicity. Cancer 2001, 91, 1826-1833. 
42. Kim, C.K.; Han, J.H. Lymphatic delivery and pharmacokinetics of methotrexate after intramuscular injection of differently charged liposome-entrapped methotrexate to rats. J. Microencapsul. 1995, 12, 437-446.

43. Ceruti, M.; Crosasso, P.; Brusa, P.; Arpicco, S.; Dosio, F.; Cattel, L. Preparation, characterization, cytotoxicity and pharmacokinetics of liposomes containing water-soluble prodrugs of paclitaxel. J. Control. Release 2000, 63, 141-153.

44. Paolino, D.; Cosco, D.; Racanicchi, L.; Trapasso, E.; Celia, C.; Iannon, M.; Puxeddu, E.; Costante, G.; Filetti, S.; Russo, D.; et al., Gemcitabine-loaded PEGylated unilamellar liposomes vs GEMZAR: biodistribution, pharmacokinetic features and in vivo antitumor activity. J. Control. Release 2010, 144, 144-50.

45. Dalla Pozza, E.; Lerda, C.; Costanzo, C.; Donadelli, M.; Dando, I.; Zoratti, E.; Scupoli, M.T.; Beghelli, S.; Scarpa, A.; Fattal, R.; et al. Targeting gemcitabine containing liposomes to CD44 expressing pancreatic adenocarcinoma cells causes an increase in the antitumoral activity. Biochim. Biophys. Acta Biomembr. 2013, 1828, 1396-1404.

46. Kanter, P.M.; Klaich, G.M.; Bullard, G.A.; King, J.M.; Bally, M.B.; Mayer, L.D. Liposome-encapsulated vincristine: Preclinical toxicologic and pharmacologic comparison with free vincristine and empty liposomes in mice, rats and dogs. AntiCancer Drugs 1994, 5, 579-590.

47. Hoarau, D.; Delmas, P.; David, S.; Roux, E.; Leroux, J.C. Novel long-circulating lipid nanocapsules. Pharm. Res. 2004, 21, 1783-1789.

48. Immordino, M.L.; Dosio, F.; Cattel, L. Stealth liposomes: review of the basic science, rationale, and clinical applications, existing and potential. Int. J. Nanomed. 2006, 1, 297-315.

49. Park, J.W. Liposome-based drug delivery in breast cancer treatment. Breast Cancer Res. 2002, 4, 95-99.

50. Allen, T.M.; Cullis, P.R. Liposomal drug delivery systems: From concept to clinical applications. Adv. Drug Deliv. Rev. 2013, 65, 36-48.

51. Solomon, R.; Gabizon, A.A. Clinical pharmacology of liposomal anthracyclines: Focus on pegylated liposomal doxorubicin. Clin. Lymphoma Myeloma 2008, 8, 21-32.

52. Rafiyath, S.M.; Rasul, M.; Lee, B.; Wei, G.; Lamba, G.; Liu, D. Comparison of safety and toxicity of liposomal doxorubicin vs. conventional anthracyclines: A meta-analysis. Exp. Hematol. Oncol. 2012, 1, 10, doi:10.1186/2162-3619-1-10.

53. Barrett-Lee, P.J.; Dixon, J.M.; Farrell, C.; Jones, A.; Leonard, R.; Murray, N.; Palmieri, C.; Plummer, C.J.; Stanley, A.; Verrill, M.W. Expert opinion on the use of anthracyclines in patients with advanced breast cancer at cardiac risk. Ann. Oncol. 2009, 20, 816-827.

54. Charrois, G.; Allen, T. Drug release rate influences the pharmacokinetics, biodistribution, therapeutic activity, and toxicity of pegylated liposomal doxorubicin formulations in murine breast cancer. Biochim. Biophys. Acta 2004, 1663,167-177.

55. Laginha, K.M.; Verwoert, S.; Charrois, G.J.; Allen, T.M. Determination of doxorubicin levels in whole tumor and tumor nuclei in murine breast cancer tumors. Clin. Cancer Res. 2005, 11, 6944-6949.

56. Yang, Z.; Lu, A.; Wong, B.C.; Chen, X.; Bian, Z.; Zhao, Z; Huang, W.; Zhang, G.; Chen, H.; $\mathrm{Xu}, \mathrm{M}$. Effect of liposomes on the absorption of water-soluble active pharmaceutical ingredients via oral administration. Curr. Pharm. Des. 2013, 19, 6647-6654. 
57. Patel, H.M. Serum opsonins and liposomes: Their interaction and opsonophagocytosis. Crit. Rev. Ther. Drug Carr. Syst. 1992, 9, 39-90.

58. Juliano, R.L.; Stamp, D. The effect of particle size and charge on the clearance rates of liposomes and liposome encapsulated drugs. Biochem. Biophys. Res. Commun. 1975, 63, 651-688.

59. Ishida, T.; Harashima, H.; Kiwada, H. Liposome clearance. Biosci. Rep. 2002, 22, 197-224.

60. Liu, D.X.; Mori, A.; Huang, L. Role of liposome size and RES blockade in controlling biodistribution and tumor uptake of GM1-containing liposomes. Biochim. Biophys. Acta 1992, 1104, 95-101.

61. Mora, M.; Sagrista, M.L.; Trombetta, D.; Bonina F.P.; de Pasquale, A.; Saija, A. Design and characterization of liposomes containing long-chain N-AcylPEs for brain delivery: Penetration of liposomes incorporating GM1 into the rat brain. Pharm. Res. 2002, 19, 1430-1438.

62. Caliceti, P.; Veronese, F.M. Pharmacokinetic and biodistribution properties of poly(ethylene glycol)-protein conjugates. Adv. Drug Deliv. Rev. 2003, 55, 1261-1277.

63. Monfardini, C.; Veronese, F.M. Stabilization of substances in circulation. Bioconjug. Chem. 1998, 9, 418-450.

64. Allen, T.M.; Cheng, W.W.; Hare, J.I.; Laginha, K.M. Pharmacokinetics and pharmacodynamics of lipidic nano-particles in cancer. Anticancer Agents Med. Chem. 2006, 6, 513-523.

65. Dudley, A.C. Tumor endothelial cells. Cold Spring Harb. Perspect. Med. 2012, 2, doi:10.1101/cshperspect.a006536.

66. Chauhan, A.K.; Varma, A. A Textbook of Molecular Biotechnology 2009; I.K. Int. Publishing House Pvt. Ltd.: New Delhi, India, 2009.

67. Bae, Y.H. Drug targeting and tumor heterogeneity. J. Control. Release 2009, 133, 2-3.

68. Sawant, R.R.; Torchilin, V.P. Torchilin, challenges in development of targeted liposomal therapeutics. AAPS J. 2012, 14, 303-315.

69. Soldati, T.; Schliwa, M. Powering membrane traffic in endocytosis and recycling. Nat. Rev. Mol. Cell Biol. 2006, 7, 897-908.

70. Higashi, N.; Yamauchi, M.; Okumura, Y.; Nakanishi, M.; Sunamoto, J. Fusion between Jurkat cell and PEO-lipid modified liposome. Biochim. Biophys. Acta 1996, 1285, 183-191.

71. Koshkaryev, A.; Sawant, R.; Deshpande, M.; Torchilin, V. Immunoconjugates and long circulating systems: Origins, current state of the art and future directions. Adv. Drug Deliv. Rev. 2013, 65, 24-35.

72. Murase, Y.; Asai, T.; Katanasaka, Y.; Sugiyama, T.; Shimizu, K.; Maeda, N.; Oku, N. A novel DDS strategy, "dual-targeting", and its application for antineovascular therapy. Cancer Lett. 2010, 287, 165-171.

73. Jayaraman, M.; Ansell, S.M.; Mui, B.L.; Tam, Y.K.; Chen, J.; Du X.; Butler, D.; Eltepu, L.; Matsuda, S.; Narayanannair, J.K.; et al. Maximizing the potency of siRNA lipid nanoparticles for hepatic gene silencing in vivo. Angew. Chem. Int. Ed. Engl. 2012, 51, 8529-8533.

74. Li, W.; Nicol, F.; Szoka, F.C., Jr. GALA: A designed synthetic pH-responsive amphipathic peptide with applications in drug and gene delivery. Adv. Drug Deliv. Rev. 2004, 56, 967-985.

75. Pagano, R.E.; Weinstein, J.N. Interactions of liposomes with mammalian cells. Annu. Rev. Biophys. Bioeng. 1978, 7, 435-468.

76. Noble, G.T.; Stefanick, J.F.; Ashley, J.D.; Kiziltepe, T.; Bilgicer, B. Ligand-targeted liposome design: Challenges and fundamental considerations. Trends Biotechnol. 2014, 32, 32-45. 
77. Heath, T.D.; Fraley, R.T.; Papahadjopoulos, D. Antibody targeting of liposomes: Cell specificity obtained by conjugation of F(ab')2 to vesicle surface. Science 1980, 210, 539-541.

78. Leserman, L.D.; Barbet, J.; Kourilsky, F.; Weinstein, J.N. Targeting to cells of fluorescent liposomes covalently coupled with monoclonal antibody or protein A. Nature 1980, 288, 602-604.

79. Liao, S.Y.; Lerman, M.I.; Stanbridge, E.J. Expression of transmembrane carbonic anhydrases, CAIX and CAXII, in human development. BMC Dev. Biol. 2009, 9, doi:10.1186/1471-213X-9-22.

80. Kondo, E.; Saito, K.; Tashiro, Y.; Kamide, K.; Uno, S.; Furuya, T.; Mashita, M.; Nakajima, K.; Tsumuraya, T.; Kobayashi, N.; et al. Tumour lineage-homing cell-penetrating peptides as anticancer molecular delivery systems. Nat. Commun. 2012, doi:10.1038/ncomms1952.

81. McDonald, P.C.; Winum, J-Y.; Supuran, C.T.; Dedhar, S. Recent developments in targeting carbonic anhydrase IX for cancer therapeutics. Oncotarget 2012, 3, 84-97.

82. Supuran, C.T. Carbonic anhydrases: Novel therapeutic applications for inhibitors and activators. Nat. Rev. Drug Discov. 2008, 7, 168-181.

83. Chiche, J.; Ilc, K.; Laferriere, J.; Trottier, E.; Dayan, F.; Mazure, N.M.; Brahimi-Horn, M.C.; Pouysségur, J. Hypoxia-inducible carbonic anhydrase IX and XII promote tumor cell growth by counteracting acidosis through the regulation of the intracellular $\mathrm{pH}$. Cancer Res. 2009, 69, $358-368$.

84. Shin, H-J.; Rho, S.B.; Jung, D.C.; Han, I-O.; Oh, E-S.; Kim J-Y. Carbonic anhydrase IX (CA9) modulates tumor-associated cell migration and invasion. J. Cell Sci. 2011, 124, 1077-1087.

85. Neri, D.; Supuran, C.T. Interfering with $\mathrm{pH}$ regulation in tumours as a therapeutic strategy. Nat. Rev. Drug Discov. 2011, 10, 767-777.

86. Olive, P.L.; Aquino-Parsons, C.; MacPhail, S.H.; Liao, S.Y.; Raleigh, J.A.; Lerman, M.I.; Stanbridge, E.G. Carbonic anhydrase 9 as an endogenous marker for hypoxic cells in cervical cancer. Cancer Res. 2001, 61, 8924-8929.

87. Tureci, O.; Sahin, U.; Vollmar, E.; Siemer, S.; Gottert, E.; Seitz, G.; Parkkilal, A.K.; Shah, G.N.; Grubb, J.H.; Pfreundschuh, M. Human carbonic anhydrase XII: cDNA cloning, expression, and chromosomal localization of a carbonic anhydrase gene that is overexpressed in some renal cell cancers. Proc. Natl. Acad. Sci. USA 1998, 95, 7608-7613.

88. Pastorekova, S.; Zatovicova, M.; Pastorek, J. Cancer-associated carbonic anhydrases and their inhibition. Curr. Pharm. Des. 2008, 14, 685-698.

89. Opavsky, R.; Pastorekova, S.; Zelnik, V.; Gibadulinova, A.; Stanbridge, E.J.; Zavada, J.; Kettmannd, R.; Pastorek, J. Human $M N / C A 9$ gene, a novel member of the carbonic anhydrase family: Structure and exon to protein domain relationships. Genomics 1996, 33, 480-487.

90. De Simone, G.; Supuran, C.T. Carbonic anhydrase IX: Biochemical and crystallographic characterization of a novel antitumor target. Biochim. Biophy. Acta Proteins Proteomics 2010, 1804, 404-409.

91. Innocenti, A.; Pastorekova, S.; Pastorek, J.; Scozzafava, A.; de Simone G.; Supuran, C.T. The proteoglycan region of the tumor-associated carbonic anhydrase isoform IX acts as anintrinsic buffer optimizing $\mathrm{CO}_{2}$ hydration at acidic $\mathrm{pH}$ values characteristic of solid tumors. Bioorg. Med. Chem. Lett. 2009, 19, 5825-5828.

92. Supuran, C.T. Carbonic anhydrase IX: A new drug target for designing diagnostic tools and antitumor agents. Hacettepe J. Biol. Chem. 2009, 37, 259-270. 
93. Swietach, P.; Hulikova, A.; Vaughan-Jones, R.D.; Harris, A.L. New insights into the physiological role of carbonic anhydrase IX in tumour pH regulation. Oncogene 2010, 29, 6509-6521.

94. Swietach, P.; Patiar, S.; Supuran, C.T.; Harris, A.L.; Vaughan-Jones, R.D. The role of carbonic anhydrase 9 in regulating extracellular and intracellular $\mathrm{pH}$ in three-dimensional tumor cell growths. J. Biol. Chem. 2009, 284, 20299-20310.

95. Saarnio, J.; Parkkila, S.; Parkkila, A.K.; Haukipuro, K.; Pastorekova, S.; Pastorek, J.; Kairaluoma, M.I.; Karttunen, T.J. Immunohistochemical study of colorectal tumors for expression of a novel transmembrane carbonic anhydrase, MN/CA IX, with potential value as a marker of cell proliferation. Am. J. Pathol. 1998, 153, 279-285.

96. Saarnio, J.; Parkkila, S.; Parkkila, A.K.; Waheed, A.; Casey, M.C.; Zhou, X.Y.; Kairaluoma, M.I.; Karttunen, T.T. Immunohistochemistry of carbonic anhydrase isozyme IX (MN/CA IX) in human gut reveals polarized expression in the epithelial cells with the highest proliferative capacity. J. Histochem. Cytochem. 1998, 46, 497-504.

97. Svastova, E.; Zilka, N.; Zat'ovicova, M.; Gibadulinova, A.; Ciampor, F.; Pastorek, J.; Pastoreková, S. Carbonic anhydrase IX reduces E-cadherin-mediated adhesion of MDCK cells via interaction with ß-catenin. Exp. Cell Res. 2003, 290, 332-345.

98. Cianchi, F.; Vinci, M.C.; Supuran, C.T.; Peruzzi, B.; de Giuli, P.; Fasolis, G.; Perigli, G.; Pastorekova, S.; Papucci, L.; Pini, A.; et al. Selective inhibition of carbonic anhydrase IX decreases cell proliferation and induces ceramide-mediated apoptosis in human cancer cells. J. Pharmacol. Exp. Ther. 2010, 334, 710-719.

99. Chen, J.; Rocken, C.; Hoffmann, J.; Kruger, S.; Lendecke, U.; Rocco, A.; Pastorekova, S.; Malfertheiner, P.; Ebert, M.P.A. Expression of carbonic anhydrase 9 at the invasion front of gastric cancers. Gut 2005, 54, 920-927.

100. Turner, J.R.; Odze, R.D.; Crum, C.P.; Resnick, M.B. MN antigen expression in normal, preneoplastic, and neoplastic esophagus: A clinicopathological study of a new cancer-associated biomarker. Hum. Pathol. 1997, 28, 740-744.

101. Ilie, M.; Mazure, N.M.; Hofman, V.; Ammadi, R.E.; Ortholan, C.; Bonnetaud, C.; Mouroux, J.; Pouysségur, J.; Hofman, P. High levels of carbonic anhydrase IX in tumour tissue and plasma are biomarkers of poor prognostic in patients with non-small cell lung cancer. Br. J. Cancer 2010, 102, 1627-1635.

102. Kim, S.J.; Rabbani, Z.N.; Dewhirst, M.W.; Vujaskovic, Z.; Vollmer, R.T.; Schreiber, E.G.; Oosterwijk, E.; Kelley, M.J. Expression of HIF-1 $\alpha$, CA IX, VEGF, and MMP-9 in surgically resected non-small cell lung cancer. Lung Cancer 2005, 49, 325-335.

103. Swinson, D.E.B.; Jones, J.L.; Richardson, D.; Wykoff, C.; Turley, H.; Pastorek, J.; Taub, N.; Harris, A.L.; O’Byrne, K.J. Carbonic anhydrase IX expression, a novel surrogate marker of tumor hypoxia, is associated with a poor prognosis in non-small-cell lung cancer. J. Clin. Oncol. 2003, 21, 473-482.

104. Chia, S.K.; Wykoff, C.C.; Watson, P.H.; Han, C.; Leek, R.D.; Pastorek, J.; Gatter, K.C.; Ratcliffe, P.; Harris, A.L. Prognostic significance of a novel hypoxia-regulated marker, carbonic anhydrase IX, in invasive breast carcinoma. J. Clin. Oncol. 2001, 19, 3660-3668. 
105. Tan, E.Y.; Yan, M.; Campo, L.; Han, C.; Takano, E.; Turley H.; Candiloro, I.; Pezzella, F.; Gatter, K.C.; Millar, E.K.A.; et al. The key hypoxia regulated gene CAIX is upregulated in basal-like breast tumours and is associated with resistance to chemotherapy. Br. J. Cancer 2009, 100, 405-411.

106. Trastour, C.; Benizri, E.; Ettore, F.; Ramaioli, A.; Chamorey, E.; Pouyssegur, J.; Berra, E. HIF-1 $\alpha$ and CA IX staining in invasive breast carcinomas: Prognosis and treatment outcome. Int. J. Cancer 2007, 120, 1451-1458.

107. Kockar, F.; Yildrim, H.; Sagkan, R.I.; Hagemann, C.; Soysal, Y.; Anacker, J.; Hamza, A.A.; Vordermark, D.; Flentje, A.; Said, H.M. Hypoxia and cytokines regulate carbonic anhydrase 9 expression in hepatocellular carcinoma cells in vitro. World J. Clin. Oncol. 2012, 3, 82-91.

108. Yu, S.-J.; Yoon, J.-H.; Lee, J.-H.; Myung, S.-J.; Jang, E.-S.; Kwak, M.-S.; Cho, E.-J.; Jang, J.-J.; Kim, Y.-J.; Lee, H.-S. Inhibition of hypoxia-inducible carbonic anhydrase-IX enhances hexokinase II inhibitor-induced hepatocellular carcinoma cell apoptosis. Acta Pharmacol. Sin. 2011, 32, 912-920.

109. Kim, J.Y.; Shin, H.J.; Kim, T.H.; Cho, K.H.; Shin, K.H.; Kim, B.K.; Roh, J.W.; Lee, S.; Park, S.Y.; Hwang, Y.J.; et al. Tumor-associated carbonic anhydrases are linked to metastases in primary cervical cancer. J. Cancer Res. Clin. Oncol. 2006, 132, 302-308.

110. Lee, S.; Shin, H.J.; Han, I.O.; Hong, E.K.; Park, S.Y.; Roh, J.W.; Shin, K.H.; Kim. T.H.; Kim, J.Y. Tumor carbonic anhydrase 9 expression is associated with the presence of lymph node metastases in uterine cervical cancer. Cancer Sci. 2007, 98, 329-333.

111. Loncaster, J.A.; Harris, A.L.; Davidson, S.E.; Logue, J.P.; Hunter, R.D.; Wycoff, C.C.; Pastorek, J.; Ratcliffe, P.J.; Stratford, I.J.; West, C.M.L. Carbonic anhydrase (CA IX) expression, a potential new intrinsic marker of hypoxia: Correlations with tumor oxygen measurements and prognosis in locally advanced carcinoma of the cervix. Cancer Res. 2001, 61, 6394-6399.

112. Woelber, L.; Kress, K.; Kersten, J.F.; Choschzick, M.; Kilic, E.; Herwig, U.; Lindner, C.; Schwarz, J.; Jaenicke; Mahner, F.S.; et al. Carbonic anhydrase IX in tumor tissue and sera of patients with primary cervical cancer. BMA Cancer 2011, 11, doi:10.1186/1471-2407-11-12.

113. Korkeila, E.; Talvinen, K.; Jaakkola, P.M.; Minn, H.; Syrjanen, K.; Sundstrom, J.; Pyrhönen, S. Expression of carbonic anhydrase IX suggests poor outcome in rectal cancer. Br. J. Cancer 2009, 100, 874-880.

114. Choschzick, M.; Oosterwijk, E.; Muller, V.; Woelber, L.; Simon, R.; Moch, H.; Tennstedt, P. Overexpression of carbonic anhydrase IX (CAIX) is an independent unfavorable prognostic marker in endometrioid ovarian cancer. Virchows Arch. 2011, 459, 193-200.

115. Hoskin, P.J.; Sibtain, A.; Daley, F.M.; Wilson, G.D. GLUTI and CAIX as intrinsic markers of hypoxia in bladder cancer: relationship with vascularity and proliferation as predictors of outcome of ARCON. Br. J. Cancer 2003, 89, 1290-1297.

116. De Schutter, H.; Landuyt, W.; Verbeken, E.; Goethals, L.; Hermans, R.; Nuyts, S. The prognostic value of the hypoxia markers CA IX and GLUT I and the cytokines VEGF and IL 6 in head and neck squamous cell carcinoma treated by radiotherapy chemotherapy. BMC Cancer 2005, 5, doi:10.1186/1471-2407-5-42 
117. Hoogsteen, I.J.; Marres, H.A.M.; Wijffels, K.; Rijken, P.; Peters, J.P.W.; van den Hoogen, F.J.A.; Oosterwijk, E.; van der Kogel, A.J.; Kaanders, J.H.A.M. Colocalization of carbonic anhydrase 9 expression and cell proliferation in human head and neck squamous cell carcinoma. Clin. Cancer Res. 2005, 11, 97-106.

118. Koukourakis, M.I.; Bentzen, S.M.; Giatromanolaki, A.; Wilson, G.D.; Daley, F.M.; Saunders, M.I.; Dische, S.; Sivridis, E.; Harris, A.L. Endogenous markers of two separate, hypoxia response pathways (hypoxia inducible factor $2 \alpha$ and carbonic anhydrase 9) are associated with radiotherapy failure in head and neck cancer patients recruited in the CHART randomized trial. J. Clin. Oncol. 2006, 24, 727-735.

119. Nordfors, K.; Haapasalo, J.; Korja, M.; Niemela, A.; Laine, J.; Parkkila, A.K.; Pastorekova, S.; Pastorek, J.; Waheed, A.; Sly, W.S.; et al. The tumour-associated carbonic anhydrases CA II, CA IX and CA XII in a group of medulloblastomas and supratentorial primitive neuroectodermal tumours: an association of CA IX with poor prognosis. BMC Cancer 2010, 10, doi:10.1186/ 1471-2407-10-148

120. Proescholdt, M.A.; Mayer, C.; Kubitza, M.; Schubert, T.; Liao, S.Y.; Stanbridge, E.J.; Ivanov, S.; Oldfield, E.H.; Brawanski, A.; Merrill, M.J. Expression of hypoxia-inducible carbonic anhydrases in brain tumors. Neuro Oncol. 2005, 7, 465-475.

121. Choi, S.W.; Kim, J.Y.; Park, J.Y.; Cha, I.H.; Kim, J.; Lee, S. Expression of carbonic anhydrase IX is associated with postoperative recurrence and poor prognosis in surgically treated oral squamous cell carcinomas. Hum. Pathol. 2008, 39, 1317-1322.

122. Eckert, A.W.; Lautner, M.H.W.; Schutze, A.; Bolte, K.; Bache, M.; Kappler, M.; Schubert, J.; Taubert, H.; Bilkenroth, U. Co-expression of Hifl $\alpha$ and CAIX is associated with poor prognosis in oral squamous cell carcinoma patients. J. Oral Pathol. Med. 2010, 39, 313-317.

123. Pastorekova, S.; Parkkila, S.; Parkkila, A.K.; Opavsky, R.; Zelnik, V.; Saarnio, J.; Pastorek, J. Carbonic anhydrase IX, MN/CA IX: Analysis of stomach complementary DNA sequence and expression in human and rat alimentary tracts. Gastroenterology 1997, 112, 398-408.

124. Gut, M.O.; Parkkila, S.; Vernerova, Z.; Rohde, E.; Zavada, J.; Hocker, M.; Pastorek, J.; Karttunen, T.; Gibadulinová, A.; Závadová, Z.; et al. Gastric hyperplasia in mice with targeted disruption of the carbonic anhydrase gene Car9. Gastroenterology 2002, 123, 1889-1903.

125. Leppilampi, M.; Karttunen, T.J.; Kivela, J.; Gut, M.O.; Pastorekova, S.; Pastorek, J.; Parkkila, S. Gastric pit cell hyperplasia and glandular atrophy in carbonic anhydrase IX knockout mice: studies on two strains C57/BL6 and BALB/C. Transgenic Res. 2005, 14, 655-663.

126. Wykoff, C.C.; Beasley, N.J.P.; Watson, P.H.; Turner, K.J.; Pastorek, J.; Sibtain, A.; Wilson, G.D.; Turley, H.; Talks, K.L.; Maxwell, P.H.; et al. Hypoxia-inducible expression of tumor-associated carbonic anhydrases. Cancer Res. 2000, 60, 7075-7083.

127. Helmlinger, G.; Yuan, F.; Dellian, M.; Jain, R.K. Interstitial $\mathrm{pH}$ and $\mathrm{pO}_{2}$ gradients in solid tumors in vivo: High-resolution measurements reveal a lack of correlation. Nat. Med. 1997, 3, 177-182.

128. Lendahl, U.; Lee, K.L.; Yang, H.; Poellinger, L. Generating specificity and diversity in the transcriptional response to hypoxia. Nat. Rev. Genet. 2009, 10, 821-832.

129. Triple-Negative Breast Cancer, 2014; National Cancer Institute: Rockville, MD, USA, 2014. 
130. Choi, J.; Kim, D.H.; Jung, W.H.; Koo, J.S. Metabolic interaction between cancer cells and stromal cells according to breast cancer molecular subtype. Breast Cancer Res. 2013, 15, doi:10.1186/bcr3472.

131. Ivanova, L.; Zandberga, E.; Silina, K.; Kalnina, Z.; Abols, A.; Endzelins, E. Vendina, I.; Romanchikova, N.; Hegmane, A.; Trapencieris, P.; et al. Prognostic relevance of carbonic anhydrase IX expression is distinct in various subtypes of breast cancer and its silencing suppresses self-renewal capacity of breast cancer cells. Cancer Chemother. Pharmacol. 2014, doi:10.1007/s00280-014-2635-1.

132. Schneider, S.A.; Sukov, W.R.; Frank, I.; Boorjian, S.A.; Costello, B.A.; Tarrell, R.F.; Thapa, P.; Thompson, R.H.; Tollefson, M.K.; Karnes, R.J.; et al. Outcome of patients with micropapillary urothelial carcinoma following radical cystectomy: ERBB2 (HER2) amplification identifies patients with poor outcome. Mod. Pathol. 2014, 27, 758-764.

133. Klatte, T.; Seligson, D.B.; Rao, J.Y.; Yu, H.; de Martino, M.; Kawaoka, K.; Wong, S.G. Belldegrun, A.S.; Pantuck, A.J. Carbonic anhydrase IX in bladder cancer: A diagnostic, prognostic, and therapeutic molecular marker. Cancer 2009, 115, 1448-1458.

134. Mitra, A.B.; Murty, V.V.; Pratap, M.; Sodhani, P.; Chaganti, R.S. ERBB2 (HER2/neu) oncogene is frequently amplified in squamous cell carcinoma of the uterine cervix. Cancer Res. 1994, 54, 637-639.

135. Pappas, A.; Lagoudianakis, E.; Seretis, C.; Tsiambas, E.; Koronakis, N.; Toutouzas, K.; Katergiannakis, V.; Manouras, A. Clinical role of HER-2/neu expression in colorectal cancer. J. BUON 2013, 18, 98-104.

136. Fleming, G.F.; Sill, M.W.; Darcy, K.M.; McMeekin, D.S.; Thigpen, J.T.; Adler, L.M.; Berekg, J.S.; Chapmanh, J.A.; DiSilvestroi, P.A.; Horowitz, I.R.; et al. Phase II trial of trastuzumab in women with advanced or recurrent, HER2-positive endometrial carcinoma: A Gynecologic Oncology Group study. Gynecol. Oncol. 2010, 116, 15-20.

137. Sadlecki, P.; Bodnar, M.; Grabiec, M.; Marszalek, A.; Walentowicz, P. The role of Hypoxia-inducible factor-1 $\alpha$, glucose transporter-1, (GLUT-1) and carbon anhydrase IX in endometrial cancer patients. Biomed. Res. Int. 2014, 2014, doi:org/10.1155/2014/616850.

138. Tanner, M.; Hollmen, M.; Junttila, T.T.; Kapanen, A.I.; Tommola, S.; Soini, Y.; Helin, H.; Salo, J.; Joensuu, H.; Sihvo, S.; et al., Amplification of HER-2 in gastric carcinoma: association with Topoisomerase II $\alpha$ gene amplification, intestinal type, poor prognosis and sensitivity to trastuzumab. Ann. Oncol. 2005, 16, 273-278.

139. Driessen, A.; Landuyt, W.; Pastorekova, S.; Moons, J.; Goethals, L.; Haustermans, K.; Nafteux, P.; Penninckx, F.; Geboes, K.; Lerut, T.; et al. Expression of carbonic anhydrase IX (CA IX), a hypoxia-related protein, rather than ascular-endothelial growth factor (VEGF), a pro-angiogenic factor, correlates with an extremely poor prognosis in esophageal and gastric adenocarcinomas. Ann. Surg. 2006, 243, 334-340.

140. Ali, M.A.; Gunduz, M.; Gunduz, E.; Tamamura, R.; Beder, L.B.; Katase, N.; Hatipoglu, O.F.; Fukushima, K.; Yamanaka, N.; Shimizu, K. Expression and mutation analysis of her2 in head and neck squamous cell carcinoma. Cancer Investig. 2010, 28, 495-500. 
141. Koukourakis, M.I.; Giatromanolaki, A.; Sivridis, E.; Simopoulos, K.; Pastorek, J.; Wykoff, C.C.; Gatter, K.C.; Harris, A.L. Hypoxia-regulated carbonic anhydrase-9 (CA9) relates to poor vascularization and resistance of squamous cell head and neck cancer to chemoradiotherapy. Clin. Cancer Res. 2001, 7, 3399-3403.

142. Wang, H.; Liu, C.; Han, J.; Zhen, L.; Zhang, T.; He X.; Xu, E.; Li, M. HER2 expression in renal cell carcinoma is rare and negatively correlated with that in normal renal tissue. Oncol. Lett. 2012, 4, 194-198.

143. Genega, E.M. Carbonic anhydrase IX expression in renal neoplasms: Correlation with tumor type and grade. Am. J. Clin. Pathol. 2010, 134, 873-879.

144. Heinmoller, P.; Gross, C.; Beyser, K.; Schmidtgen, C.; Maass, G.; Rüschoff, J. Pedrocchi M HER2 status in non-small cell lung cancer: Results from patient screening for enrollment to a phase II study of herceptin. Clin. Cancer Res. 2003, 9, 5238-5243.

145. Hanken, H.; Gaudin, R.; Grobe, A.; Fraederich, M.; Eichhorn, W.; Smeets, R.; Simon, R.; Sauter, G.; Grupp, H.; Izbicki, J.R. Her2 expression and gene amplification is rarely detectable in patients with oral squamous cell carcinomas. J. Oral Pathol. Med. 2014, 43, 304-308.

146. Lanitis, E.; Dangaj, D.; Hagemann, I.S.; Song, D.G.; Best, A.; Sandaltzopoulos, R.; George, C.; Daniel, J.P., Jr. Primary human ovarian epithelial cancer cells broadly express HER2 at immunologically-detectable levels. PLoS One 2012, 7, e49829.

147. Jorda, M.; Morales, A.; Ghorab, Z.; Fernandez, G.; Nadji, M.; Block, N. Her2 expression in prostatic cancer: A comparison with mammary carcinoma. J. Urol. 2002, 168, 1412-1414.

148. Smyth, L.G.; O’Hurley, G.; O’Grady, A.; Fitzpatrick, J.M.; Kay, E.; Watson, R.W.G. Carbonic anhydrase IX expression in prostate cancer. Prostate Cancer Prostatic. Dis. 2010, 13, 178-181.

149. Oosterwijk, E.; Ruiter, D.J.; Hoedemaeker, P.J.; Pauwels, E.K.J.; Jonas, U.; Zwartendijk, J.; Warnaar, S.O. Monoclonal antibody G 250 recognizes a determinant present in renal-cell carcinoma and absent from normal kidney. Int. J. Cancer 1986, 38, 489-494.

150. Pastorek, J.; Pastorekova, S.; Callebaut, I.; Mornon, J.P.; Zelnik, V.; Opavsky, R.; Zat'ovicová M.; Liao, S.; Portetelle, D.; Stanbridge, E.J. Cloning and characterization of MN, a human tumor-associated protein with a domain homologous to carbonic anhydrase and a putative helix-loop-helix DNA binding segment. Oncogene 1994, 9, 2877-2888.

151. Grabmaier, K.; Vissers, J.L.M.; de Weijert, M.C.A.; Oosterwijk-Wakka, J.C.; van Bokhoven, A.; Brakenhoff, R.H.; Noessner, E.; Mulders, P.A.; Merkx, G.; Figdor, C.G. Molecular cloning and immunogenicity of renal cell carcinoma-associated antigen G250. Int. J. Cancer 2000, 85, 865-870.

152. Surfus, J.E.; Hank, J.A.; Oosterwijk, E.; Welt, S.; Lindstrom, M.J.; Albertini, M.R.; Schiller, J.H.; Sondel, P.M. Anti-renal-cell carcinoma chimeric antibody G250 facilitates antibody-dependent cellular cytotoxicity with in vitro and in vivo interleukin-2-activated effectors. J. Immunother. 1996, 19, 184-191.

153. Liu, Z.Q.; Smyth, F.E.; Renner, C.; Lee, F.T.; Oosterwijk, E.; Scott, A.M. Anti-renal cell carcinoma chimeric antibody G250: Cytokine enhancement of in vitro anti body-dependent cellular cytotoxicity. Cancer Immunol. Immunother. 2002, 51, 171-177. 
154. Belldegrun, A.S.; Chamie, K.; Kloepfer, P.; Fall, B.; Bevan, P.; Stoerkel, S.; Wilhelm, O.; Pantuck, A.J. ARISER: A randomized double blind phase III study to evaluate adjuvant cG250 treatment versus placebo in patients with high-risk ccRCC-Results and implications for adjuvant clinical trials. In Proceedings of 2013 ASCO Annual Meeting, Chicago, IL, USA, 31 May-4 June, 2013; Abstract Number 4507.

155. Bleumer, I.; Knuth, A.; Oosterwijk, E.; Hofmann, R.; Varga, Z.; Lamers, C.; Kruit, W.; Melchior, S.; Mala, C.; Ullrich, S.; et al. A phase II trial of chimeric monoclonal antibody G250 for advanced renal cell carcinoma patients. Br. J. Cancer 2004, 90, 985-990.

156. Davis, I.D.; Wiseman, G.A.; Lee, F-T.; Gansen, D.N.; Hopkins, W.; Papenfuss, A.T.; Liu, L.; Moynihan, T.J.; Croghan, G.A.; Adjei, A.A. A phase I multiple dose, dose escalation study of cG250 monoclonal antibody in patients with advanced renal cell carcinoma. Cancer Immun. 2007, 7, 13-13.

157. Bleumer, I.; Oosterwijk, E.; Oosterwijk-Wakka, J.C.; Voller, M.C.W.; Melchior, S.; Warnaar, S.O.; Mala, C.; Beck, J.; Mulders, P.F.A. A clinical trial with chimeric monoclonal antibody WX-G250 and low dose interleukin-2 pulsing scheme for advanced renal cell carcinoma. J. Urol. 2006, 175, $57-62$.

158. Davis, I.D.; Liu, Z.; Saunders, W.; Lee, F-T.; Spirkoska, V.; Hopkins, W.; Smyth, F.E.; Chong, G.; Papenfuss, A.T.; Chappell, B.; et al. A pilot study of monoclonal antibody cG250 and low dose subcutaneous IL-2 in patients with advanced renal cell carcinoma. Cancer Immun. 2007, 7, 14-14.

159. Siebels, M.; Rohrmann, K.; Oberneder, R.; Stahler, M.; Haseke, N.; Beck, J.; Hofmann, R.; Kindler, M.; Kloepfer, P.; Stief, C. A clinical phase I/II trial with the monoclonal antibody cG250 $\left(\right.$ RENCAREX $\left.^{\circledR}\right)$ and interferon- $\alpha-2 \mathrm{a}$ in metastatic renal cell carcinoma patients. World J. Urol. 2011, 29, 121-126.

160. Zatovicova, M.; Jelenska, L.; Hulikova, A.; Csaderova, L.; Ditte, Z.; Ditte, P.; Goliasova, T.; Pastorek, J.; Pastorekova, S. Carbonic anhydrase IX as an anticancer therapy target: Preclinical evaluation of internalizing monoclonal antibody directed to catalytic domain. Curr. Pharm. Des. 2010, 16, 3255-3263.

161. Petrul, H.M.; Schatz, C.A.; Kopitz, C.C.; Adnane, L.; McCabe, T.J.; Trail, P.; Ha, S.; Chang, Y.S.; Voznesensky, A.; Ranges, G.; et al. Therapeutic mechanism and efficacy of the antibody-drug conjugate BAY 79-4620 targeting human carbonic anhydrase 9. Mol. Cancer Ther. 2012, 11, 340-349.

162. Manjappa, A.S.; Chaudhari, K.R.; Venkataraju, M.P.; Dantuluri, P.; Nanda, B.; Sidda, C.; Krutika, S.K.; Murthy, R.S.R. Antibody derivatization and conjugation strategies: Application in preparation of stealth immunoliposome to target chemotherapeutics to tumor. J. Control. Release 2011, 150, 2-22.

163. Braden, B.C.; Goldman, E.R.; Mariuzza, R.A.; Poljak, R.J. Anatomy of an antibody molecule: Structure, kinetics, thermodynamics and mutational studies of the antilysozyme antibody D1.3. Immunol. Rev. 1998, 163, 45-57.

164. Goding, J.W. Monoclonal Antibodies: Principles and Practice; Acadmic Press Inc.: San Dirgo, CA, USA, 1986. 
165. Ravdin, P.M.; Chamness, G.C. The c-erbB-2 proto-oncogene as a prognostic and predictive marker in breast cancer: a paradigm for the development of other macromolecular markers-A review. Gene 1995, 159, 19-27.

166. Slamon, D.J.; Clark, G.M.; Wong, S.G.; Levin, W.J.; Ullrich, A.; McGuire, W.L. Human breast cancer: correlation of relapse and survival with amplification of the HER-2/neu oncogene. Science 1987, 235, 177-182.

167. Kirpotin, D.B.; Drummond, D.C.; Shao, Y.; Shalaby, M.R.; Hong, K.L.; Nielsen, U.B.; Marks, J.D.; Benz, C.C.; Park, J.W. Antibody targeting of long-circulating lipidic nanoparticles does not increase tumor localization but does increase internalization in animal models. Cancer Res. 2006, 66, 6732-6740.

168. Stefanick, J.F.; Ashley, J.D.; Kiziltepe, T.; Bilgicer, B. A systematic analysis of peptide linker length and liposomal polyethylene glycol coating on cellular uptake of peptide-targeted liposomes. ACS Nano 2013, 7, 2935-2947.

169. Goren, D.; Horowitz, A.T.; Zalipsky, S.; Woodle, M.C.; Yarden, Y.; Gabizon, A. Targeting of stealth liposomes to erbB-2 (Her/2) receptor: In vitro and in vivo studies. Br. J. Cancer 1996, 74, 1749-1756.

170. Tuscano, J.M.; Martin, S.M.; Ma, Y.; Zamboni, W.; O’Donnell, R.T. Efficacy, biodistribution, and pharmacokinetics of CD22-targeted pegylated liposomal doxorubicin in a B-cell non-hodgkin's lymphoma xenograft mouse model. Clin. Cancer Res. 2010, 16, 2760-2768.

171. Sapra, P.; Moase, E.H.; Ma, J.; Allen, T.M. Improved therapeutic responses in a xenograft model of human B lymphoma (Namalwa) for liposomal vincristine versus liposomal doxorubicin targeted via anti-CD19 IgG2a or Fab' fragments. Clin. Cancer Res. 2004, 10, 1100-1111.

172. Alshaer, W.; Hillaireau, H.; Vergnaud, J.; Ismail, S.; Fattal, E. Functionalizing liposomes with anti-CD44 aptamer for selective targeting of cancer cells. Bioconjug. Chem. 2014, doi:10.1021/bc5004313

173. Hatakeyama, H.; Akita, H.; Ishida, E.; Hashimoto, K.; Kobayashi, H.; Aoki, T.; Yasuda, J.; Obata, K.; Kikuchi, H.; Ishid, T.; et al. Tumor targeting of doxorubicin by anti-MT1-MMP antibody-modified PEG liposomes. Int. J. Pharm. 2007, 342, 194-200.

174. Mamot, C.; Ritschard, R.; Wicki, A.; Stehle, G.; Dieterle, T.; Bubendorf, L.; Hilker, C.; Deuster, S.; Herrmann, R.; Rochlitz, C. Tolerability, safety, pharmacokinetics, and efficacy of doxorubicin-loaded anti-EGFR immunoliposomes in advanced solid tumours: A phase 1 dose-escalation study. Lancet Oncol. 2012, 13, 1234-1241.

175. Matsumura, Y.; Gotoh, M.; Muro, K.; Yamada, Y.; Shirao, K.; Shimada, Y.; Okuwa, M.; Matsumoto, S.; Miyata, Y.; Ohkura, H. Phase I and pharmacokinetic study of MCC-465, a doxorubicin (DXR) encapsulated in PEG immunoliposome, in patients with metastatic stomach cancer. Ann. Oncol. 2004, 15, 517-525.

176. Tiwari, G.; Tiwari, R.; Sriwastawa, B.; Bhati, L.; Pandey, S.; Pandey, P.; Bannerjee, S.K. Drug delivery systems: An updated review. Int. J. Pharm. Investig. 2012, 2, 2-11.

177. Chang, H.-I.; Yeh, M.-K. Clinical development of liposome-based drugs: Formulation, characterization, and therapeutic efficacy. Int. J. Nanomed. 2012, 7, 49-60. 
178. Shinkai, M.; Le, B.; Honda, H.; Yoshikawa, K.; Shimizu, K.; Saga, S.; Wakabayashi, T.; Yoshida, J.; Kobayashi, T. Targeting hyperthermia for renal cell carcinoma using human MN antigen-specific magnetoliposomes. JNP J. Cancer Res. 2001, 92, 1138-1145.

179. Askoxylakis, V.; Ehemann, V.; Rana, S.; Krämer, S.; Rahbari, N.N.; Debus, J.; Haberkorn, U. Binding of the phage display derived peptide CaIX-P1 on human colorectal carcinoma cells correlates with the expression of carbonic anhydrase IX. Int. J. Mol. Sci. 2012, 13, 13030-13048.

180. Askoxylakis, V.; Garcia-Boy, R.; Rana, S.; Krämer, S.; Hebling, U.; Mier, W.; Altmann, A.; Markert, A.; Debus, J.; Haberkorn, U. A new peptide ligand for targeting human carbonic anhydrase IX, identified through the phage display technology. PLoS One 2010, 5, e15962.

(C) 2014 by the authors; licensee MDPI, Basel, Switzerland. This article is an open access article distributed under the terms and conditions of the Creative Commons Attribution license (http://creativecommons.org/licenses/by/4.0/). 